\title{
Klippel-Trenaunay syndrome, an unusual association with persistent lateral marginal vein of Servelle: colour Doppler and 256 dual-source MDCT evaluation
}

\author{
Lalit Garg, ${ }^{1}$ Umesh Kumar Mittal, ${ }^{2}$ Sunil Kumar Puri, ${ }^{3}$ Harmeet Kaur Rissam ${ }^{2}$
}

${ }^{1}$ Department of

Radiodiagnosis, G B Pant Hospital, New Delhi, India ${ }^{2} \mathrm{G}$ B Pant Hospital, New Delhi, India

${ }^{3}$ Department of Radiology, G B Pant Hospital, New Delhi, India

\section{Correspondence to} Dr Umesh Kumar Mittal, dr.umeshmittal@yahoo.co.in

Accepted 8 June 2015
To cite: Garg L, Mittal UK, Puri SK, et al. BMJ Case Rep Published online: [please include Day Month Year] doi:10.1136/bcr-2015210051

\section{DESCRIPTION}

A 35-year-old woman presented with pain, skin discolouration, and gradually increasing swelling and dilation of the veins of the left lower limb. On examination, there was dilation and tortuosity of the superficial veins of the left lower limb, limb hypertrophy and port wine stain.

Colour Doppler imaging revealed incompetence of the left saphenofemoral junction. The distal segment of left popliteal vein (proximal segment was normal), left sapheno-popliteal junction were not visualised and replaced by multiple dilated venous collaterals. Incompetent perforators were noted in the lower leg. Superficial dilated veins revealed wall thickening consistent with superficial thrombophlebitis (figure 1).

CT angiography revealed multiple haemangiomas in the subcutaneous and intermuscular plane with phleboliths. Multiple serpentine varicosities involving the entire left leg and significant limb hypertrophy were noted (figure 2). A large thick-walled oedematous venous channel was seen arising near the lateral malleolus, coursing along the lateral aspect of the left leg and reaching up to the popliteal fossa, probably due to persistence of the lateral marginal vein of servelle. ${ }^{1}$ Partial thrombus was noted in the proximal segment of the popliteal vein. The deep venous system beyond the proximal segment of the popliteal vein was not visualised (figure 3).

The patient is being managed conservatively on low-dose heparin. No active radiological or surgical intervention was performed.

Klippel-Trenaunay syndrome (nevus vasculosus steohypertrophicus) is a complex congenital anomaly including capillary malformations, soft tissue or bony hypertrophy and varicose veins or venous malformations. ${ }^{2} 3$ It has no arteriovenous shunting, the absence of which, notably, differentiates it from Parkes Weber syndrome.

Important differential diagnoses include Parkes Weber syndrome, Maffucci syndrome, neurofibromatosis type 1, Beckwith-Wiedemann syndrome and macrodystrophia lipomatosis.
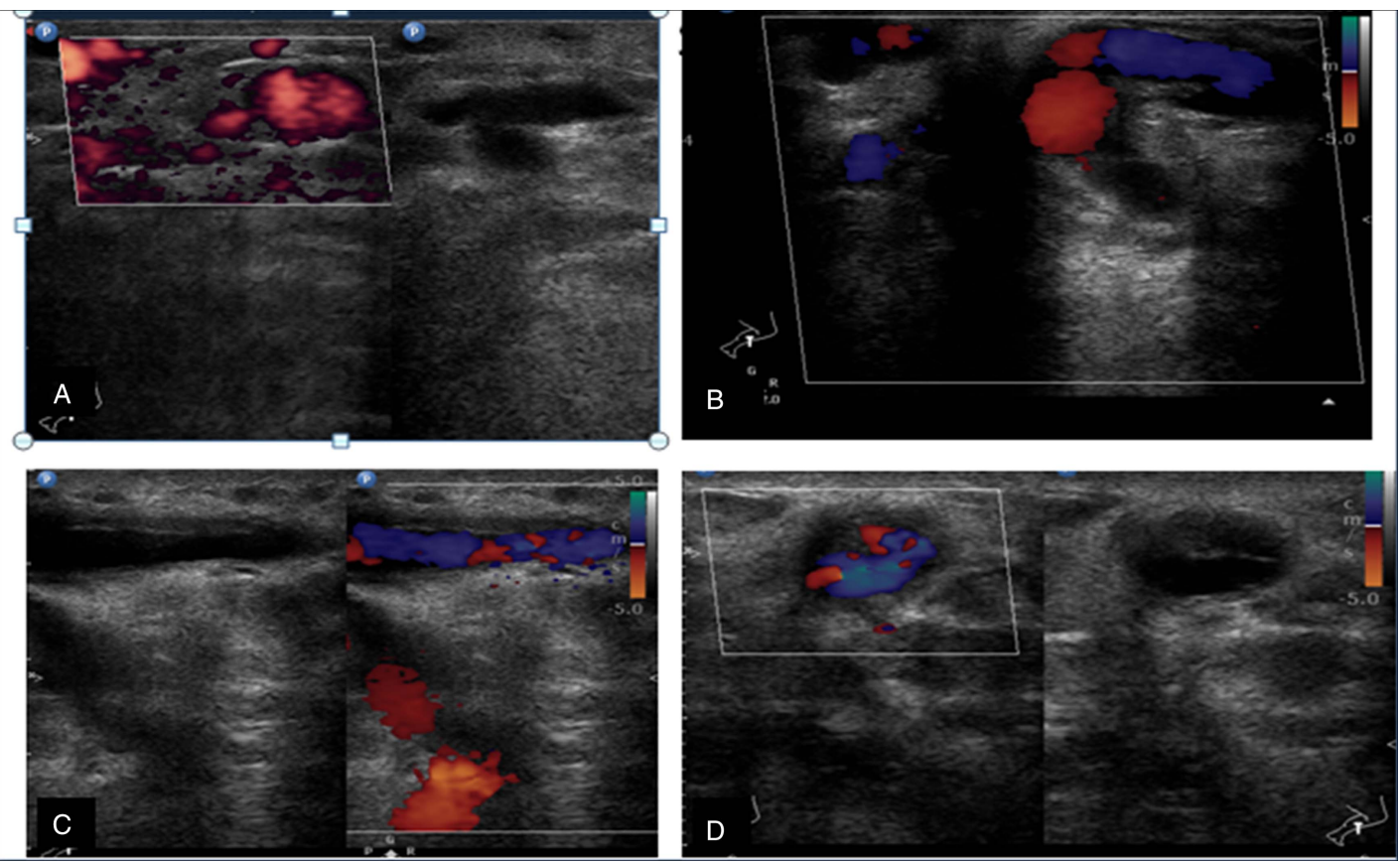

Figure 1 ( $A$ and $B$ ) Colour Doppler images of left lower limb showing multiple varicosities. (C and D) Images showing thickened lateral marginal vein of Servelle. 

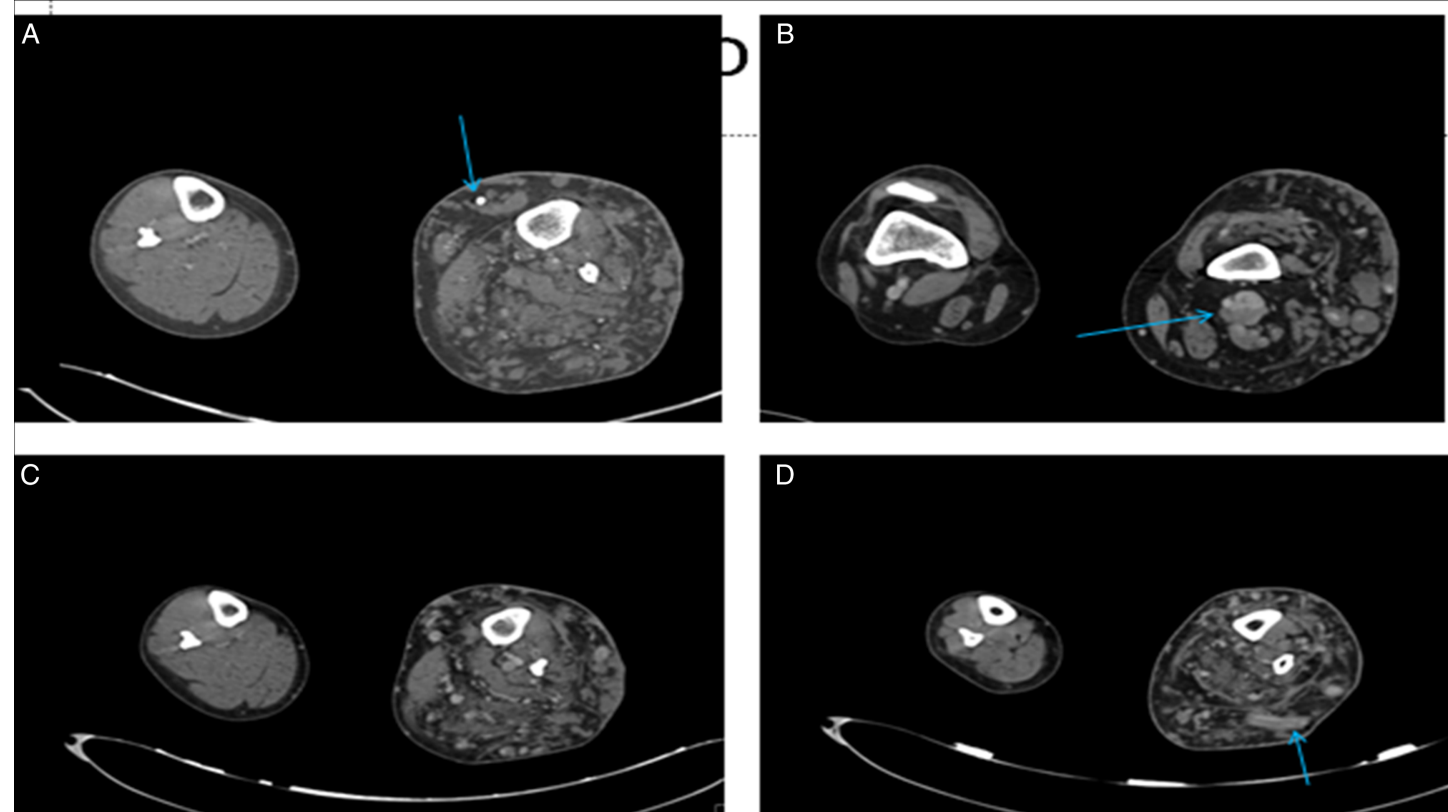

Figure 2 (A and B) Axial contrast-enhanced CT scans showing haemangiomas with phlebolith (arrow in A), soft tissue hypertrophy, partial thrombus in popliteal vein (arrow in B). (C and D) Axial CT scans showing multiple varicosities and thrombophlebitis of superficial vein (arrow in D).
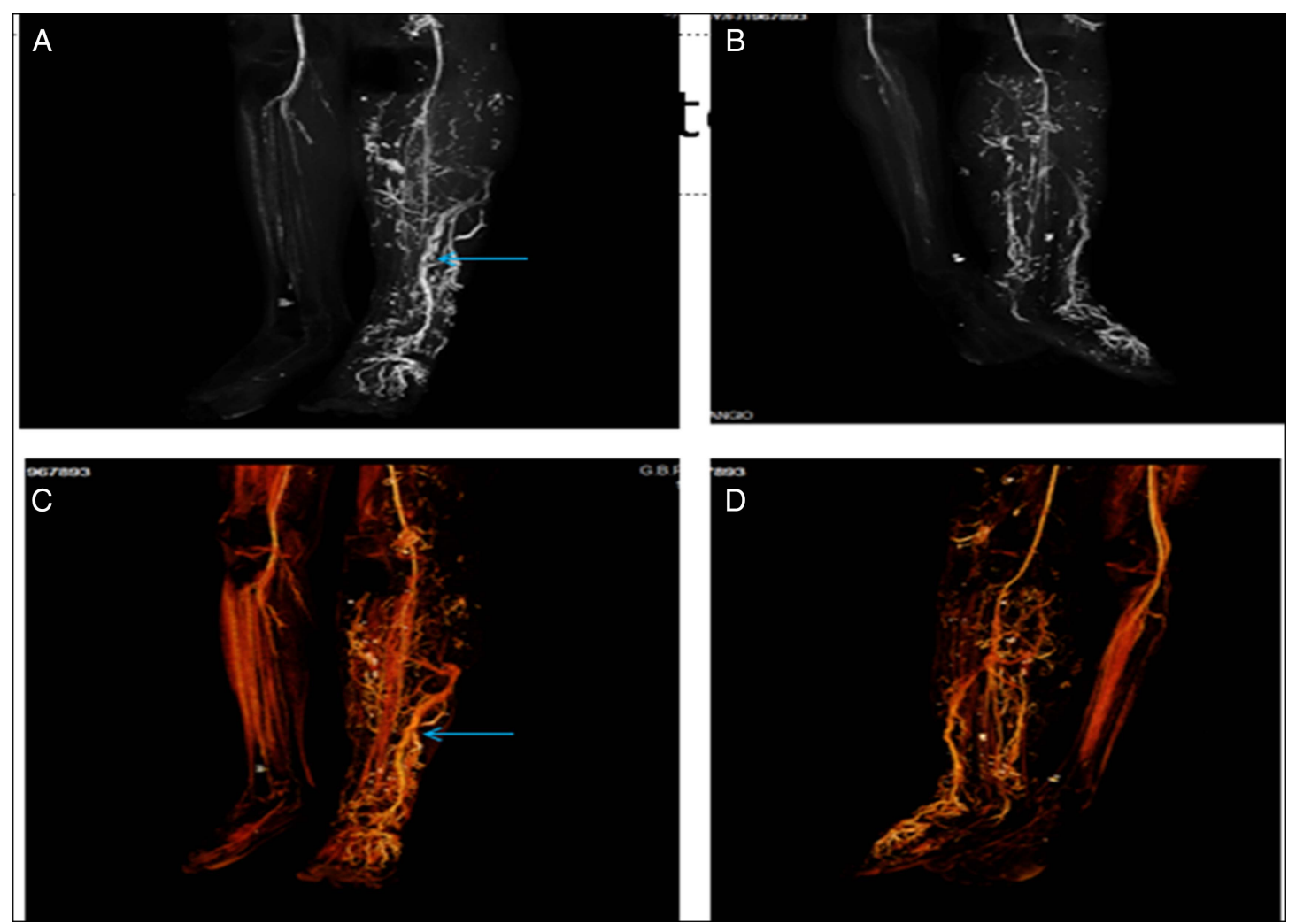

Figure 3 ( $A$ and $B$ ) Maximum intensity projection and (C and D) volume rendering technique showing lateral marginal vein of Servelle (arrow in $A$ and C), limb hypertrophy, multiple varicosities and hypoplastic deep venous system. 


\section{Learning points}

- Klippel-Trenaunay syndrome is a rare congenital anomaly associated with various venous malformations, limb hypertrophy and port-wine stains.

- Detailed preoperative mapping of the venous system by CT and MR venography is important because the symptoms can worsen if intervention is performed on dilated superficial collateral veins when hypoplasia or aplasia of the deep veins is also present.

- Lateral marginal vein of Servelle: This persistent vein is often associated with hypoplasia or aplasia of some parts of the deep venous system of the extremity, and its presence should always alert for the possibility of Klippel-Trenaunay syndrome.
Competing interests None declared.

Patient consent Obtained.

Provenance and peer review Not commissioned; externally peer reviewed.

\section{REFERENCES}

1 Rojas Martinez R, Puech-Leão P, Guimarães PM, et al. Persistence of the embryonic lateral marginal vein: report of two cases. Rev Hosp Clin Fac Med Sao Paulo 2001;56:159-62.

2 Lee $A$, Driscoll D, Gloviczki $P$, et al. Evaluation and management of pain in patients with Klippel-Trenaunay syndrome: a review. Pediatrics 2005;115:744-9.

3 Biesecker LG, Happle R, Mulliken JB, et al. Proteus syndrome: diagnostic criteria, differential diagnosis, and patient evaluation. Am J Med Genet 1999;84:389-95

Copyright 2015 BMJ Publishing Group. All rights reserved. For permission to reuse any of this content visit http://group.bmj.com/group/rights-licensing/permissions.

BMJ Case Report Fellows may re-use this article for personal use and teaching without any further permission.

Become a Fellow of BMJ Case Reports today and you can:

- Submit as many cases as you like

- Enjoy fast sympathetic peer review and rapid publication of accepted articles

- Access all the published articles

- Re-use any of the published material for personal use and teaching without further permission

For information on Institutional Fellowships contact consortiasales@bmjgroup.com

Visit casereports.bmj.com for more articles like this and to become a Fellow 